Çukurova Üniversitesi Mühendislik Fakültesi Dergisi, 36(1), ss. 121-130, Mart 2021

Cukurova University Journal of the Faculty of Engineering, 36(1), pp. 121-130, March 2021

\title{
Çeşitli Dayanımlara Sahip Atık Betonlardan Üretilen Geri Kazanılmış Agregaların Fiziksel ve Geomekanik Özellikleri
}

\author{
Hasan DILBAS ${ }^{* 1}$ \\ ${ }^{1}$ Yüzzüncü Yıl Üniversitesi, Mühendislik Fakültesi, Inşaat Mühendisliği Bölümü, Van
}

Geliş tarihi: 01.02.2021

Kabul tarihi: 31.03 .2021

$\ddot{\mathbf{O} z}$

$\mathrm{Bu}$ basit ve kapsamlı çalışma, geri kazanılmış agreganın (RA) temel özelliklerini araştırmaktadır ve mevcut agrega standartlarına ek olarak, bu makale RA'nın yoğunluğunu ve su absorpsiyonunu kısa sürede tahmin etmek için basit bir tahmin yaklaşımını önermektedir. Bilindiği gibi, fiziksel testler uzun zaman almaktadır (yaklaşık 72 saat) ve atığın hızlı karakterizasyonu, özellikle geri dönüşüm tesisleri için daha önemlidir. Dolayısıyla, sonuçları genelleştirmek için yapılan testlerde düşük, orta ve yüksek dayanımlı atık betonlardan üretilen RA'lar dikkate alınmıştır. RA'nın temel özellikleri yoğunluk ve su absorpsiyonu olarak kabul edilebilir ve RA'ların geomekanik özelliklerini belirlemek için nokta yük testi kullanılmıştır. Nokta yük testinin dikkate alınmasının nedenleri, testin basitliği ve kısa test süresidir. Elde edilen deney sonuçları dikkate alınarak incelemelerde bulunulmuştur. Ayrıca, RA'nın fiziksel özelliklerini, nokta yük dayanım indeksi (Is(50)) kullanılarak tahmin etmek için denklemler önerilmiş ve tatmin edici sonuçlar elde edilmiştir.

Anahtar Kelimeler: Geri kazanılmış agrega, Noktasal yükleme deneyi, Fiziksel özellikler, Regresyon analizi

\section{Physical and Geomechanical Properties of Recycled Aggregate Sourced by Various Grade Concrete Wastes}

\begin{abstract}
This simple and comprehensive study investigates main properties of recycled aggregate (RA) and, in addition to current aggregate standards, this paper proposes a simple prediction approach to estimate density and water absorption of RA in a short time. As well-known, physical tests take a long time (approximately 72 hours), and rapid characterization of the waste is more important especially for recycling plants. Hence, in this paper low, medium, and high strength concrete wastes are considered as RA in the tests to generalize the results. The main properties of RA are accepted as water absorption and density and point load test is employed to determine geomechanical property of RAs. The reasons of the consideration of the point load test are the simplicity of the test and the short test duration. Then, the test results are evaluated and examined. Equations to predict the physical properties of RA using the point load strength index $(\mathrm{Is}(50))$ are proposed and satisfactory results are obtained.
\end{abstract}

Keywords: Recycled aggregate, Point load test, Physical properties, Regression analysis

"Sorumlu yazar (Corresponding author): Hasan DİLBAS, hasandilbas@yyu.edu.tr 
Çeşitli Dayanımlara Sahip Atık Betonlardan Üretilen Geri Kazanılmış Agregaların Fiziksel ve Geomekanik Özellikleri

\section{INTRODUCTION}

Recycled aggregate (RA) is produced from construction and demolition wastes (CDW) and defined as a concrete material in the last century [1]. The waste problem has been tried to solve in past decades and many research were conducted on CDW to use as RA in concrete (i.e., [2-6]). However, RA presents a variety and has many structural parts such as concrete, marble, PVC, plaster, styropor, gypsum, and tile. Consideration of concrete waste $(\mathrm{CW})$ only in the production of RA limits the undesired the properties of resulting concrete. Because, if RA is sourced by marble, PVC, plaster, styropor, etc., RA negatively effects the performance of recycled aggregate concrete (RAC) reducing the physical and the mechanical properties.

In this view, the properties of RA and RA feature detection speed in tests gain importance. Because tests for complete properties RA take many times and this may cause waste of time. Hence, prediction of properties of RA instead of determination of whole properties of RA comes ahead, and some prediction methods are proposed for this topic. For instance, the relation between water absorption and density of RA is well-known and conversion formulas are proposed in the literature using statistical methods [7]. It is seen that the research of RA on rapid property estimation are rarely found in the literature.

In this research paper, geomechanical, physical and origin properties of RAs sourced by low strength, medium strength and high strength concrete wastes are employed. At first, source concrete properties are determined. Then, at second RA properties are obtained conducting many tests. In the last part, analytical examination is performed, and predicted results are compared with experimental data.

\section{MATERIALS AND METHOD}

In this study, all strength grades of $\mathrm{CWs}$ are considered and 20 cores with $100 \mathrm{~mm}$ diameter and $200 \mathrm{~mm}$ height are tested under compression load for each grade of CWs (Table 1) (low strength
(<20 MPa), medium strength (20-40 MPa), and high strength (40 MPa $>$ ) [8]).

Table 1. RA source parameters and notations of RAs

\begin{tabular}{|l|c|c|c|c|}
\hline \multirow{2}{*}{ Notations } & \multicolumn{4}{|c|}{ RA source strength } \\
\cline { 2 - 5 } & $\begin{array}{c}\text { No. of } \\
\text { test data }\end{array}$ & Average & $\begin{array}{c}\text { Standard } \\
\text { deviation }\end{array}$ & $\begin{array}{c}\text { Strength grade } \\
{[8]}\end{array}$ \\
\hline RA-L & 20 & $10.8 \mathrm{MPa}$ & $1.4 \mathrm{MPa}$ & Low $(<20 \mathrm{MPa})$ \\
\hline RA-M & 20 & $34.5 \mathrm{MPa}$ & $1.1 \mathrm{MPa}$ & $\begin{array}{c}\text { Medium } \\
(20 \mathrm{MPa}-40 \\
\mathrm{MPa})\end{array}$ \\
\hline RA-H & 20 & $45.4 \mathrm{MPa}$ & $0.9 \mathrm{MPa}$ & High $(40 \mathrm{MPa}>)$ \\
\hline
\end{tabular}

Thus, a generalized comprehensive study can be made, and the results are able to be compared. Here, RA sourced by low, medium, and high-grade CWs are named as RA-L, RA-M and RA-H, respectively. CWs are sourced by structural concrete element parts. CW is crushed into parts using lab type jaw crusher. Many CW particles (these are RAs) for each strength grade are employed to determine the geomechanical (point load strength index (Is(50)) and the physical (water absorption and density) properties according to the standards (Table 2-5).

Table 2. Tests applied to RAs

\begin{tabular}{|c|c|c|c|}
\hline Parameters & Test & $\begin{array}{c}\text { No. of } \\
\text { data }\end{array}$ & Standard \\
\hline Is(50) & Point load test & 39 & ASTM D5731[11] \\
\hline \%WA & $\begin{array}{c}\text { Water } \\
\text { absorption test }\end{array}$ & 39 & TS EN 12390-7[12] \\
\hline D & Density test & 39 & TS EN 12390-7[12] \\
\hline
\end{tabular}

Point load test is utilized in general to characterize the rock strength and, also can be considered to predict the other properties of rocks. However, in this paper, the test is employed to define Is(50) of RAs and its relation with other RA properties considering irregular shaped samples (Figure 1).

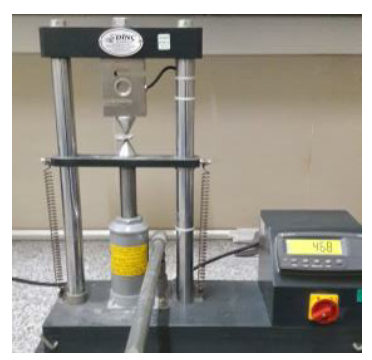

Figure 1. Point load test machine 
Table 3. The geomechanical and the physical test results of RA-L

\begin{tabular}{|c|c|c|c|c|c|c|c|}
\hline \multirow{3}{*}{ No } & \multirow{2}{*}{\multicolumn{5}{|c|}{$\begin{array}{c}\text { Geomechanical Tests } \\
\text { Point load strength index }\end{array}$}} & \multicolumn{2}{|c|}{ Physical Tests } \\
\hline & & & & & & \multirow{2}{*}{$\begin{array}{c}\begin{array}{c}\text { Water } \\
\text { absorption test }\end{array} \\
\text { WA }(\%)\end{array}$} & \multirow{2}{*}{$\begin{array}{c}\begin{array}{c}\text { Density } \\
\text { test }\end{array} \\
\mathrm{D}\left(\mathrm{kg} / \mathrm{m}^{3}\right)\end{array}$} \\
\hline & \multicolumn{2}{|c|}{$\begin{array}{l}\text { Particle Dimensions, } \\
\text { mm }\end{array}$} & $\begin{array}{c}\text { Point } \\
\text { load, N }\end{array}$ & Is & Is (50) & & \\
\hline 1 & 38 & 22 & 284 & 0.3 & 0.2 & 4.17 & 2000 \\
\hline 2 & 39 & 16 & 438 & 0.6 & 0.4 & 12.14 & 1619 \\
\hline 3 & 34 & 18 & 682 & 0.9 & 0.7 & 2.09 & 1927 \\
\hline 4 & 34 & 23 & 430 & 0.4 & 0.4 & 2.76 & 1941 \\
\hline 5 & 31 & 28 & 1210 & 1.1 & 0.9 & 2.64 & 2187 \\
\hline 6 & 29 & 28 & 334 & 0.3 & 0.3 & 6.69 & 1713 \\
\hline 7 & 30 & 27 & 748 & 0.7 & 0.6 & 4.44 & 2015 \\
\hline 8 & 29 & 20 & 692 & 0.9 & 0.7 & 4.37 & 2025 \\
\hline 9 & 25 & 21 & 364 & 0.5 & 0.4 & 3.50 & 2000 \\
\hline 10 & 28 & 20 & 384 & 0.5 & 0.4 & 7.05 & 1819 \\
\hline 11 & 28 & 25 & 280 & 0.3 & 0.2 & 2.26 & 2076 \\
\hline 12 & 26 & 17 & 1012 & 1.8 & 1.3 & 3.56 & 2707 \\
\hline 13 & 28 & 16 & 1410 & 2.5 & 1.8 & 3.48 & 2493 \\
\hline Average & 31 & 22 & 636 & 0.8 & 0.6 & 4.55 & 2040 \\
\hline Standard deviation & 5 & 5 & 400 & 0.7 & 0.5 & 2.81 & 317.1 \\
\hline
\end{tabular}

Table 4. The geomechanical and the physical test results of RA-M

\begin{tabular}{|c|c|c|c|c|c|c|c|}
\hline \multirow{3}{*}{ No } & \multirow{2}{*}{\multicolumn{5}{|c|}{$\begin{array}{c}\text { Geomechanical Tests } \\
\text { Point load strength index }\end{array}$}} & \multicolumn{2}{|c|}{ Physical Tests } \\
\hline & & & & & & \multirow{2}{*}{$\begin{array}{c}\begin{array}{c}\text { Water } \\
\text { absorption test }\end{array} \\
\text { WA }(\%)\end{array}$} & \multirow{2}{*}{$\begin{array}{c}\begin{array}{c}\text { Density } \\
\text { test }\end{array} \\
D\left(\mathrm{~kg} / \mathrm{m}^{3}\right)\end{array}$} \\
\hline & Particl & nsions, & $\begin{array}{l}\text { Point } \\
\text { load, N }\end{array}$ & $\begin{array}{c}\text { Is } \\
(\mathbf{M P a})\end{array}$ & $\begin{array}{l}\text { Is(50) } \\
\text { (MPa) }\end{array}$ & & \\
\hline 1 & 32 & 28 & 1256 & 1.1 & 0.9 & 7.16 & 1803 \\
\hline 2 & 43 & 22 & 622 & 0.5 & 0.4 & 3.44 & 1943 \\
\hline 3 & 28 & 34 & 1018 & 0.8 & 0.7 & 4.18 & 1971 \\
\hline 4 & 38 & 25 & 2625 & 2.2 & 1.8 & 2.43 & 2200 \\
\hline 5 & 27 & 28 & 642 & 0.7 & 0.5 & 2.71 & 2514 \\
\hline 6 & 31 & 34 & 748 & 0.6 & 0.5 & 2.73 & 2071 \\
\hline 7 & 42 & 30 & 1606 & 1.0 & 0.9 & 2.04 & 2587 \\
\hline 8 & 39 & 30 & 2070 & 1.4 & 1.2 & 3.26 & 2151 \\
\hline 9 & 40 & 18 & 410 & 0.4 & 0.4 & 3.40 & 2801 \\
\hline 10 & 30 & 28 & 664 & 0.6 & 0.5 & 1.98 & 3011 \\
\hline 11 & 40 & 21 & 1026 & 1.0 & 0.8 & 3.43 & 2095 \\
\hline 12 & 34 & 21 & 1114 & 1.2 & 1.0 & 6.09 & 2172 \\
\hline 13 & 28 & 28 & 1302 & 1.3 & 1.1 & 2.84 & 2152 \\
\hline Average & 35 & 27 & 1162 & 1.0 & 0.8 & 3.51 & 2267 \\
\hline Standard deviation & 6 & 5 & 496 & 0.3 & 0.3 & 1.62 & 376 \\
\hline
\end{tabular}


Çeşitli Dayanımlara Sahip Atık Betonlardan Üretilen Geri Kazanılmış Agregaların Fiziksel ve Geomekanik Özellikleri

Table 5. The geomechanical and the physical test results of RA-H

\begin{tabular}{|c|c|c|c|c|c|c|c|}
\hline \multirow{3}{*}{ No } & \multirow{2}{*}{\multicolumn{5}{|c|}{$\begin{array}{c}\text { Geomechanical Tests } \\
\text { Point load strength index }\end{array}$}} & \multicolumn{2}{|c|}{ Physical Tests } \\
\hline & & & & & & \multirow{2}{*}{$\begin{array}{c}\begin{array}{c}\text { Water } \\
\text { absorption test }\end{array} \\
\text { WA }(\%)\end{array}$} & \multirow{2}{*}{$\begin{array}{c}\begin{array}{c}\text { Density } \\
\text { test }\end{array} \\
\mathrm{D}\left(\mathrm{kg} / \mathrm{m}^{\mathbf{3}}\right)\end{array}$} \\
\hline & Partic & nsions, & $\begin{array}{c}\text { Point } \\
\text { load, N }\end{array}$ & $\begin{array}{c}\text { Is } \\
\text { (MPa) }\end{array}$ & $\begin{array}{l}\text { Is(50) } \\
\text { (MPa) }\end{array}$ & & \\
\hline 1 & 33 & 36 & 2056 & 1.4 & 1.2 & 0.87 & 2101 \\
\hline 2 & 32 & 40 & 2062 & 1.3 & 1.1 & 3.64 & 2556 \\
\hline 3 & 30 & 42 & 1600 & 1.0 & 0.9 & 7.72 & 1839 \\
\hline 4 & 26 & 45 & 2176 & 1.5 & 1.3 & 2.85 & 2353 \\
\hline 5 & 36 & 32 & 1424 & 1.0 & 0.9 & 3.69 & 2048 \\
\hline 6 & 14 & 30 & 1430 & 2.7 & 1.9 & 3.28 & 2021 \\
\hline 7 & 42 & 20 & 1636 & 1.5 & 1.3 & 1.65 & 2811 \\
\hline 8 & 33 & 33 & 2012 & 1.5 & 1.3 & 2.69 & 2386 \\
\hline 9 & 31 & 38 & 1524 & 1.0 & 0.9 & 2.19 & 2210 \\
\hline 10 & 36 & 29 & 884 & 0.7 & 0.6 & 1.18 & 2932 \\
\hline 11 & 24 & 23 & 1388 & 2.0 & 1.5 & 2.10 & 2217 \\
\hline 12 & 29 & 28 & 1614 & 1.6 & 1.3 & 2.10 & 2547 \\
\hline 13 & 20 & 37 & 1446 & 1.5 & 1.2 & 2.29 & 2215 \\
\hline Average & 30 & 33 & 1635 & 1.4 & 1.2 & 2.79 & 2326 \\
\hline Standard deviation & 8 & 6 & 352 & 0.5 & 0.3 & 0.93 & 308 \\
\hline
\end{tabular}

\section{RESULTS}

In the experiments, the geomechanical and the physical properties of RA are determined. It is observed that the source quality influences the properties of RA. When the strength of CW increases, the geomechanical properties of RA are affected positively (Figures 2-3).

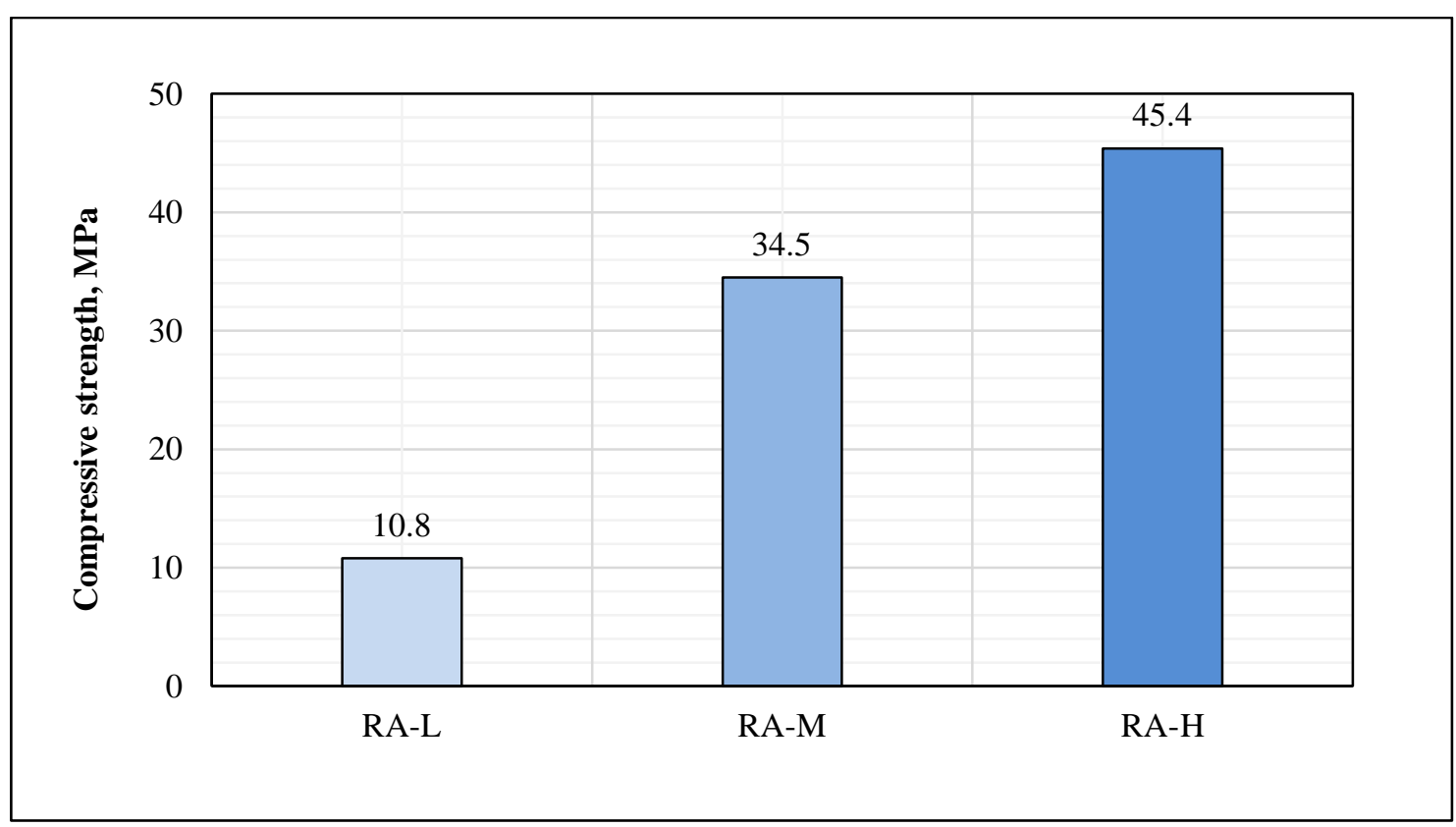

Figure 2. RA source compressive strength values 


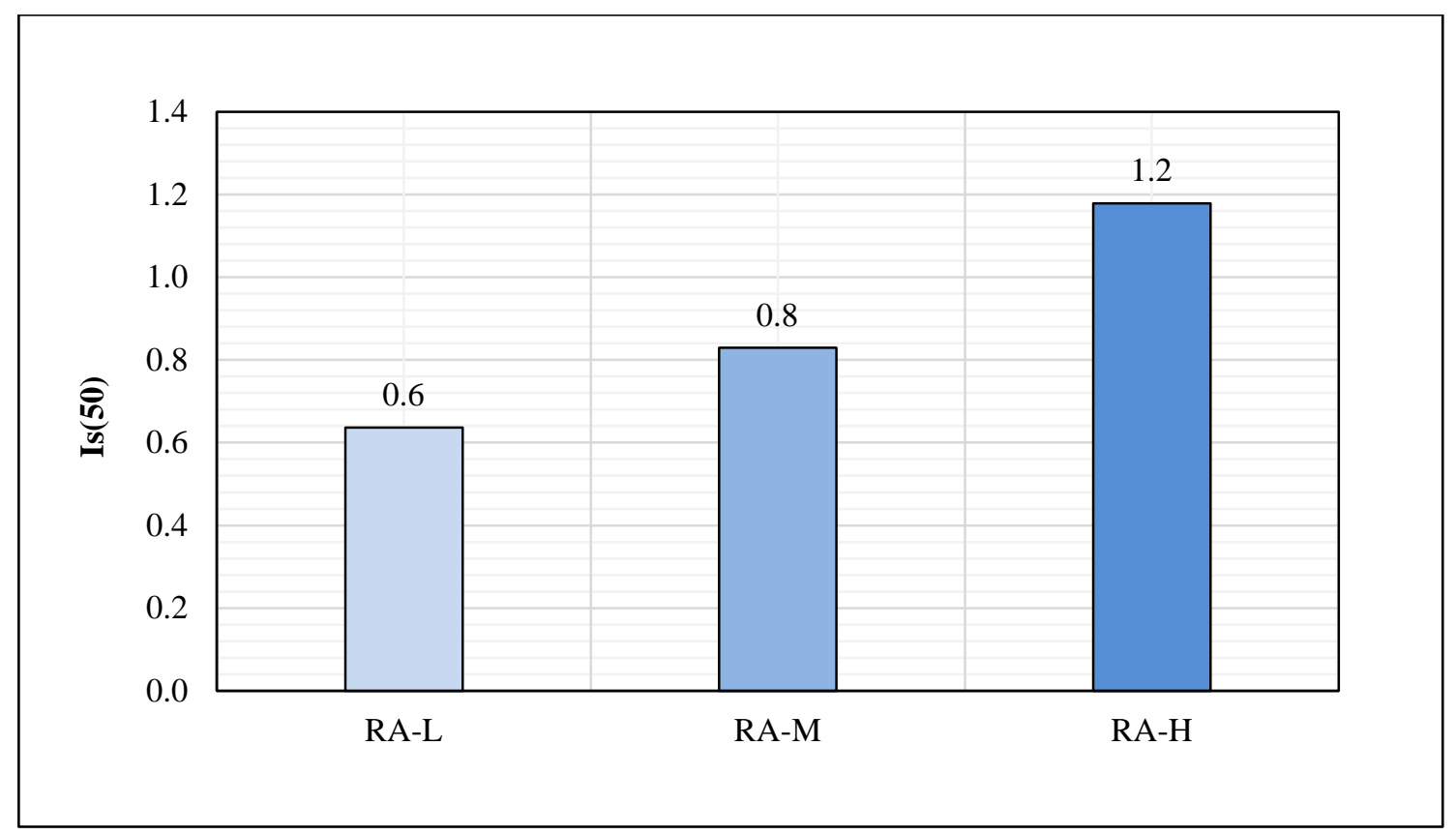

Figure 3. RA point load strength index values

For instance, source strengths of RA-L, RA-M and RA-H are $10.8 \mathrm{MPa}, 34.5 \mathrm{MPa}$ and $45.4 \mathrm{MPa}$, respectively and those of $\mathrm{Is}(50)$ values are
0.6 $\mathrm{MPa}, 0.8 \mathrm{MPa}$ and $1.2 \mathrm{MPa}$, respectively. On the other hand, the similar results are found for the physical properties (Figures 4-5).

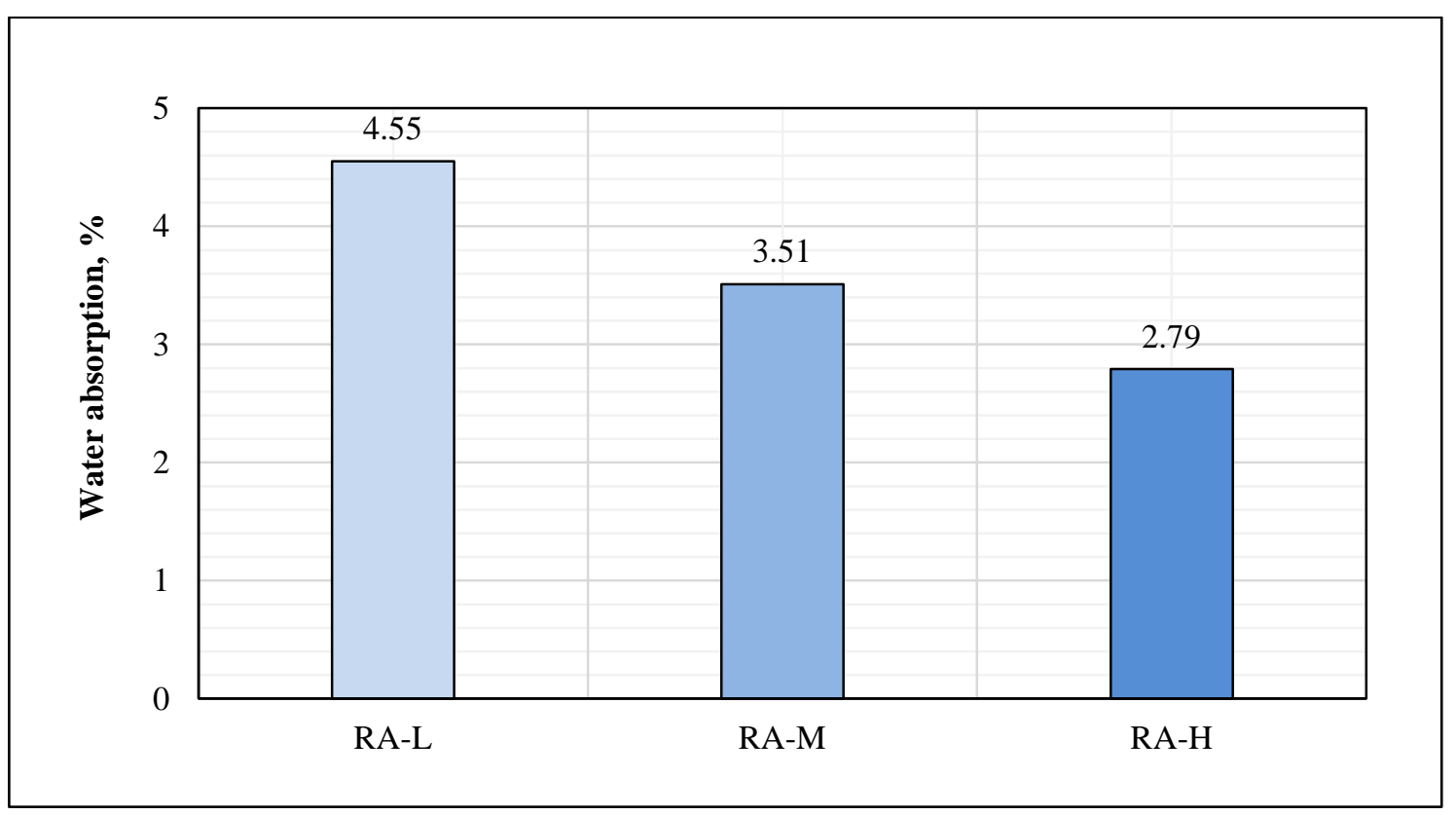

Figure 4. Water absorption vales of RAs 
Çeşitli Dayanımlara Sahip Atık Betonlardan Üretilen Geri Kazanılmış Agregaların Fiziksel ve Geomekanik Özellikleri

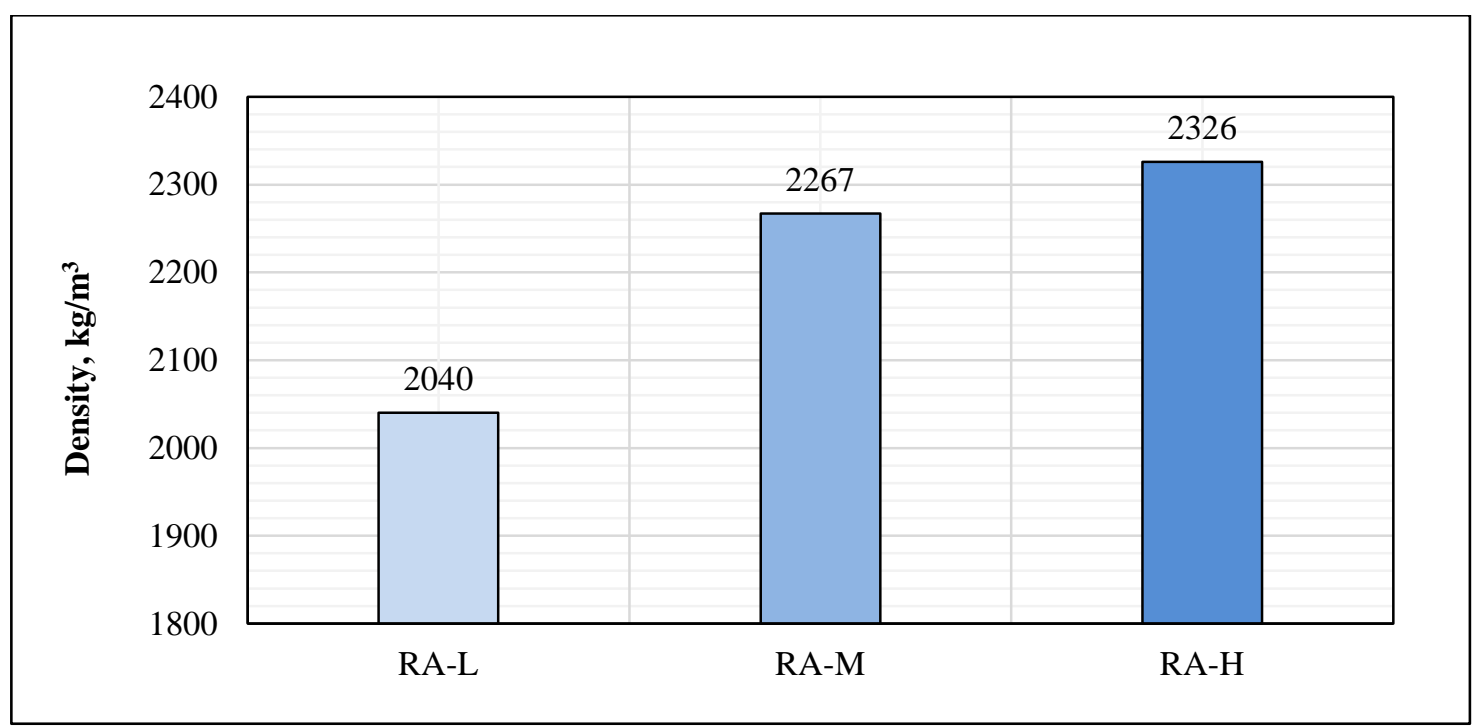

Figure 5. Density values of RAs

3.1. Evaluation of the Geomechanical and the Physical Test Results of RAs

In the literature, Silva et al. conducted a research on the related literature considering the physical properties of RA, and they divided RA qualities into four groups such as A, B, C and D (Figure 6)
[9]. In this classification, $\mathrm{A}$ is the best quality and $\mathrm{D}$ is the worse quality. According to this, the classification of RAs considered in this paper is properly determined and the qualities of RAs are found (Figure 6). It is observed that the scatter of RAs in each group is approximately homogeneous representing each aggregate class (Figure 6).

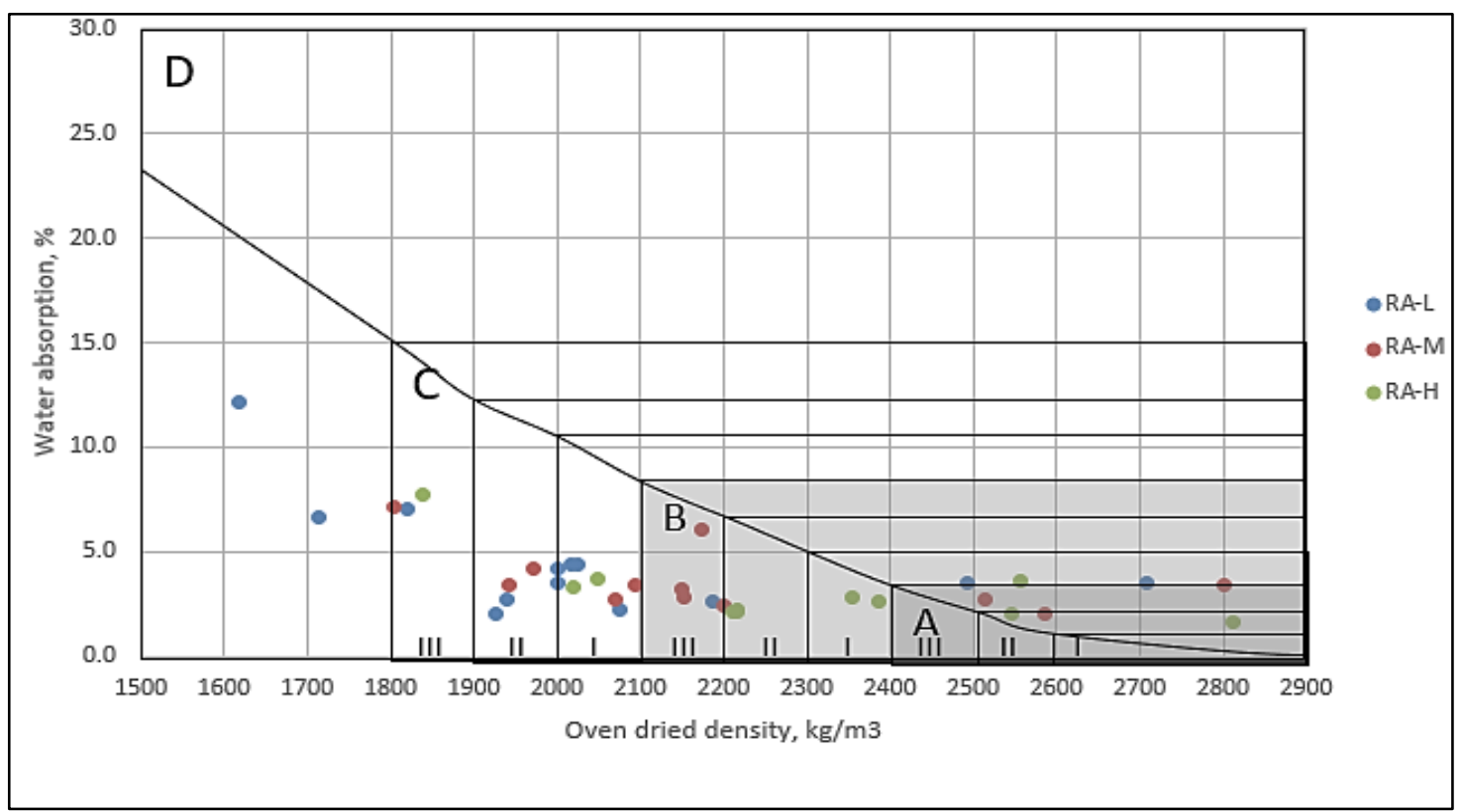

Figure 6. A, B, C and D classes of RAs according to Ref. [9] 
Then, the number of RA in A, B, C and D classes and Is(50) values of RAs for RA-L, RA-M and RA-H are determined (Table 6-7). It is found that although RA is sourced by medium/high grade, the resulting properties of RA can be worse or better and scattered after crushing process.

Table 6. The proposed A, B, C and D RA classes according to Ref. [9]

\begin{tabular}{|c|c|c|c|c|c|c|c|c|c|c|}
\hline \multirow{3}{*}{ Property } & \multicolumn{10}{|c|}{ Aggregate class } \\
\hline & \multicolumn{3}{|c|}{$\mathbf{A}$} & \multicolumn{3}{|c|}{ B } & \multicolumn{3}{|c|}{$\mathbf{C}$} & D \\
\hline & I & II & III & I & II & III & I & II & III & \\
\hline $\begin{array}{l}\text { Min. Oven dried density } \\
\left(\mathrm{kg} / \mathrm{m}^{3}\right)\end{array}$ & 2600 & 2500 & 2400 & 2300 & 2200 & 2100 & 2000 & 1900 & 1800 & Z \\
\hline Max. Water absorption (\%) & 1.5 & 2.5 & 3.5 & 5.0 & 6.5 & 8.5 & 10.5 & 13 & 15 & $\bar{\Xi}$. \\
\hline $\begin{array}{l}\text { Max. Los Angeles abrassion } \\
\text { mass loss }(\%)\end{array}$ & \multicolumn{3}{|c|}{40} & \multicolumn{3}{|c|}{45} & \multicolumn{3}{|c|}{50} & \\
\hline
\end{tabular}

Table 7. Number of RA in A, B, C and D RA quality classes

\begin{tabular}{|c|c|c|c|c|}
\hline \multirow{2}{*}{ Source } & \multicolumn{4}{|c|}{ Number of aggregates in aggregate class } \\
\cline { 2 - 5 } & A & B & C & D \\
\hline RA-L & 2 & 1 & 8 & 2 \\
\hline RA-M & 4 & 4 & 5 & 0 \\
\hline
\end{tabular}

For instance, RAs in $\mathrm{A}, \mathrm{B}$ and $\mathrm{C}$ classes are obtained from RA-L, RA-M and RA-H. However, D class RA is obtained from RA-L only and high strength source results higher quality RAs generally. In the literature, the effects of RA source quality is investigated and it is found that only RA sourced by low quality $\mathrm{CW}$ resulted worse effects on the resulting concrete [10]. Table 8-9 show an atlas of Is(50) of RAs examined in this paper and mean that when RA quality class increases, the average value of point load strength index increases.

Table 8. Determined point load strength index (Is(50)) average values of RA classes

\begin{tabular}{|c|c|c|c|c|}
\hline \multirow{2}{*}{ Class } & \multicolumn{5}{|c|}{ Is(50), MPa } \\
\cline { 2 - 5 } & I & II & III & Average in aggregate class \\
\hline A & 1.10 & 0.96 & 1.53 & 1.20 \\
\hline B & 1.07 & 1.24 & 0.98 & 1.10 \\
\hline C & 0.67 & 0.48 & 0.83 & 0.66 \\
\hline D & \multicolumn{5}{|c|}{0.35} & 0.35 \\
\hline
\end{tabular}

Table 9. Determined point load strength index min-max values of RA classes

\begin{tabular}{|c|c|c|c|c|}
\hline \multirow{2}{*}{ Class } & \multicolumn{4}{|c|}{ Is(50), MPa } \\
\hline & $\mathbf{I}$ & II & III & Min-max in aggregate class \\
\hline $\mathbf{A}$ & $0.50-1.89$ & $0.36-1.48$ & $1.29-1.77$ & $0.36-1.89$ \\
\hline B & $0.90-1.24$ & $0.58-1.84$ & $0.91-1.06$ & $0.58-1.84$ \\
\hline $\mathbf{C}$ & $0.25-1.30$ & $0.22-0.71$ & $0.41-1.15$ & $0.22-1.30$ \\
\hline D & \multicolumn{3}{|c|}{$0.26-0.43$} & $0.26-0.43$ \\
\hline
\end{tabular}

However, the scattered data of Is(50) of RAs due to attached old mortar (AOM) causes a large gap in min-max values of Is(50). The physical test results for each RA class is given in Table 10-11.
It can be seen that from $\mathrm{D}$ to $\mathrm{A}$ class the water absorption of RA decreases and the density of RA increases. 
Çeşitli Dayanımlara Sahip Atık Betonlardan Üretilen Geri Kazanılmış Agregaların Fiziksel ve Geomekanik Özellikleri

Table 10. Determined water absorption vales of RAs

\begin{tabular}{|c|c|c|c|c|}
\hline \multirow{2}{*}{ Class } & \multicolumn{4}{|c|}{ Is(50), MPa } \\
\cline { 2 - 5 } & I & II & III & Average in aggregate class \\
\hline A & 1.6 & 2.8 & 3.5 & 2.6 \\
\hline B & 3.1 & 2.3 & 3.9 & 3.1 \\
\hline C & 3.5 & 3.3 & 7.3 & 4.7 \\
\hline D & \multicolumn{5}{|c|}{} \\
\hline
\end{tabular}

Table 11. Determined density vales of RAs

\begin{tabular}{|c|c|c|c|c|}
\hline \multirow{2}{*}{ Class } & \multicolumn{4}{|c|}{ Is(50), MPa } \\
\hline & $\mathbf{I}$ & II & III & Average in aggregate class \\
\hline $\mathbf{A}$ & 2918 & 2565 & 2600 & 2694 \\
\hline $\mathbf{B}$ & 2252 & 2211 & 2171 & 2211 \\
\hline $\mathbf{C}$ & 2044 & 1956 & 1820 & 1940 \\
\hline D & \multicolumn{3}{|c|}{1666} & 1666 \\
\hline
\end{tabular}

\subsection{Analytical Examinations of Test Results}

In this section, the geomechanical and the physical test results are examined and the relations between the properties are determined (Figures 7-8).

Figures 7-8 includes the average values for each class of RA. The trend line of the relations is determined and the analytical relations with high accuracy between the parameters are found $\left(\mathrm{R}^{2} \approx 0.7\right)$.
The values of RAs in class D drawn in Figures 7-8 are thought to be deviated unsimilar to those of RAs in classes A, B and C. However, when the data is eliminated in the analytical examinations, $\mathrm{R}^{2}$ of the equations found in Figures 7-8 get so little. This shows that the meaningfulness of the equations gets worse. Thus, it is concluded that the data is important for the graphs and equations and it is not deviated from others.

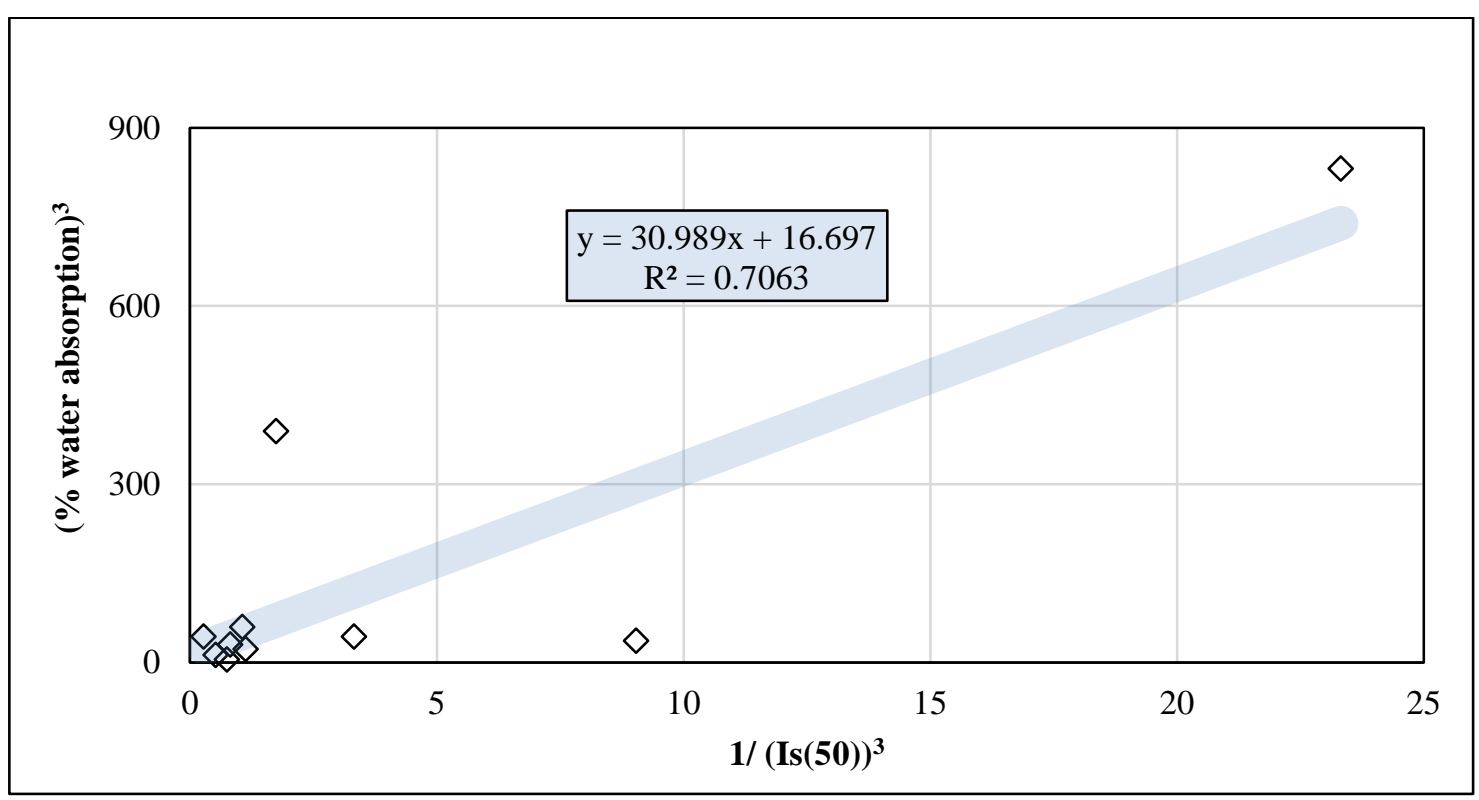

Figure 7. Water absorption and point load strength index relation 


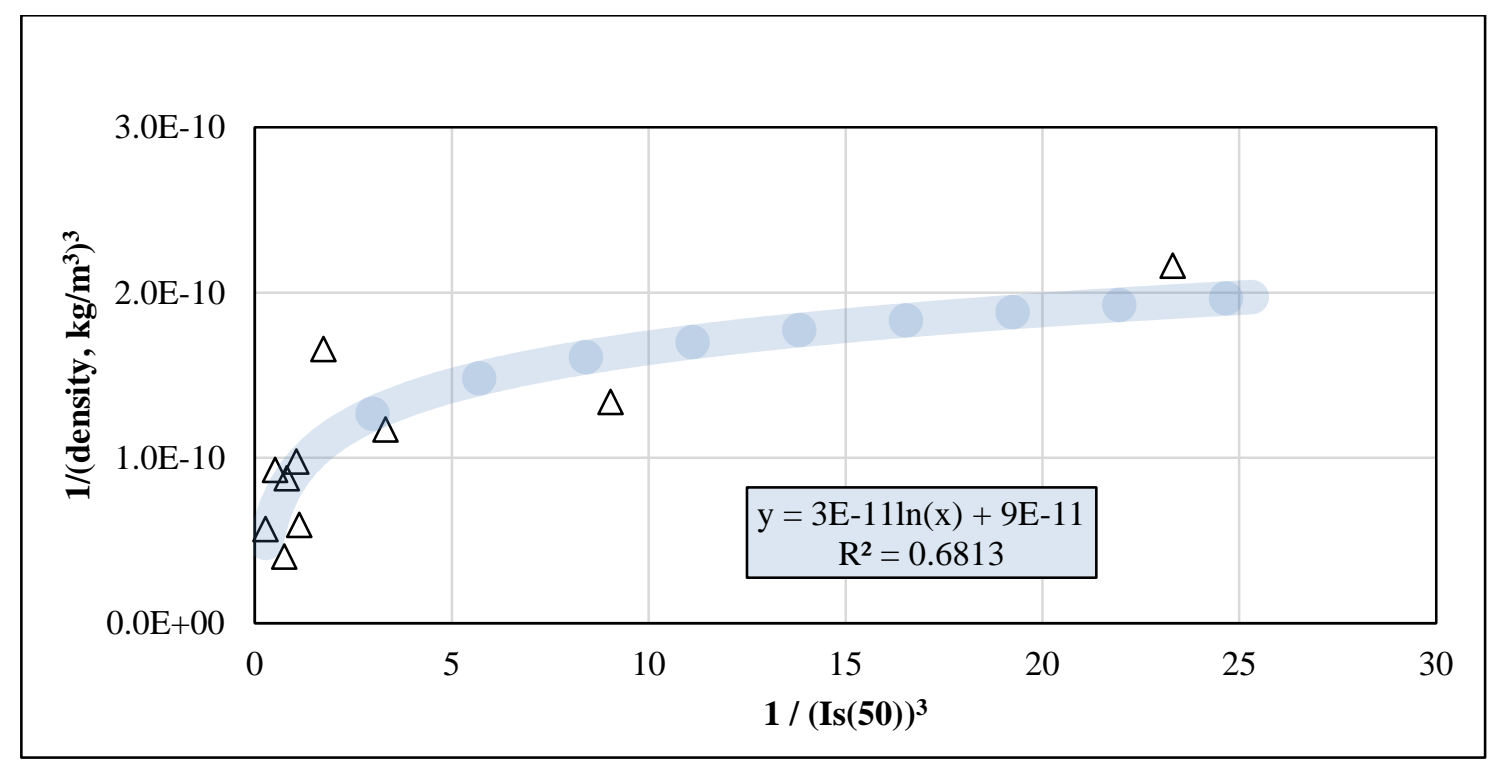

Figure 8. Density and point load strength index relation

The best fitted equations are given in Equation 1-2. It is observed that there is a non-linear relation between the geomechanical and the physical properties of RA. It can be stated that the equations predict the water absorption and the density of RA considering only point load strength index value with a short duration. Thus, it ensures an idea on the physical properties of RA and the grade of RA.

$$
\begin{aligned}
& \mathrm{WA}=\sqrt[3]{\frac{32.078}{(\operatorname{Is}(50))^{3}}} \\
& \mathrm{D}=\sqrt[3]{\frac{1}{3 \mathrm{E}-11 \ln \left(\frac{1}{\operatorname{Is}(50)}\right)+9 \mathrm{E}-11}}
\end{aligned}
$$

where WA is water absorption of RA (\%), Is(50) is point load strength index of RA (MPa), D is density of RA $\left(\mathrm{kg} / \mathrm{m}^{3}\right)$.

\section{CONCLUSIONS}

In this paper, the geomechanical and the physical properties of recycled aggregates (RAs) sourced by low, medium, and high strength concrete wastes
(CW) are investigated. Also, the analytical examinations are conducted on the properties. Following conclusions based on the test results are drawn:

- RA quality classification can be used for RAs and an increase in the strength of CW causes an increase in the properties of RA.

- The geomechanical properties such as point load strength index is a parameter that can be simply determined in a short time and can be used for RA. Also, there is a relation between the point load strength index and main physical properties of RA (i.e., water absorption and density).

- The proposed equations have an opportunity to give an idea for the main physical properties of RA and it depends on the point load test result that is determined in a short time.

- Recycling plants, in a normal day, transforms huge amounts of CW into RA and generally many tons of RA are stocked in the plants with no detail. Here, if it is intended to assess the properties/quality/grade of stocked RA, a long time is required. However, the proposed equations can shorten the demanded time and can be useful for the recycling plants. 


\section{REFERENCES}

1. Xiao, J., Li, W., Poon, C., 2012. Recent Studies on Mechanical Properties of Recycled Aggregate Concrete in China-A review, Sci. China Technol. Sci. 55, 1463-1480. https://doi.org/10.1007/s11431-012-4786-9.

2. Duan, Z.H., Poon, C.S., 2014. Properties of Recycled Aggregate Concrete Made with Recycled Aggregates with Different Amounts of Old Adhered Mortars, Mater. Des. 58, 19-29. https://doi.org/10.1016/j.matdes.2014. 01.044.

3. Matias, D., de Brito, J., Rosa, A., Pedro, D., 2013. Mechanical Properties of Concrete Produced with Recycled Coarse AggregatesInfluence of the Use of Superplasticizers, Constr. Build. Mater. 44, 101-109. https://doi.org/10.1016/j.conbuildmat.2013.03. 011.

4. Poon, C.S., Shui, Z.H., Lam, L., Fok, H., Kou, S.C., 2004. Influence of Moisture States of Natural and Recycled Aggregates on the Slump and Compressive Strength of Concrete, Cem. Concr. Res. 34, 31-36. https://doi.org/ 10.1016/S0008-8846(03)00186-8.

5. Sanchez, M., Gutierrez, P.A., 2004. Influence of Recycled Aggregate Quality on Concrete Properties, Proceeding of the International RILEM Conference: The Use of Recycled Materials in Building and Structures, Barcelona, Spain, 545-553.

6. Topçu, I.B., Günçan, N.F., 1995. Using Waste Concrete As Aggregate, Cem. Concr. Res. 25 1385-1390.

7. de Brito, J., Saikia, N., 2013. Recycled Aggregate in Concrete Use of Industrial, Construction and Demolition Waste, Springer, XII, 448. https://doi.org/10.1007/978-1-44714540-0.

8. Mehta, P.K., Monteiro, P.J.M., 2006. Concrete: Microstructure, Properties and Materails, Third Edit, The McGraw-Hill, New York, 684. https://doi.org/10.1036/0071462889.

9. Silva, R.V., De Brito, J., Dhir, R.K., 2014. Properties and Composition of Recycled Aggregates from Construction and Demolition Waste Suitable for Concrete Production,
Constr. Build. Mater. 65, 201-217. https://doi. org/10.1016/j.conbuildmat.2014.04.117.

10. Pedro, v de Brito, J., Evangelista, L., 2014. Influence of the Use of Recycled Concrete Aggregates from Different Sources on Structural Concrete, Constr. Build. Mater. 71, 141-151. https://doi.org/10.1016/j.conbuildmat .2014.08.030.

11. ASTM International, 2016. ASTM D5731-16 Standard Test Method for Determination of the Point Load Strength Index of Rock and Application to Rock Strength Classification, West Conshohocken, PA. https://doi.org/ 10.1520/D5731-16.

12. Turkish Standards Institution, 2013. TS EN 12390-7 Tests for Mechanical and Physical Properties of Aggregates-Part 6: Determination of Particle Density and Water Absorption, Ankara, Turkey. 